\begin{tabular}{|l|l|l||}
\hline \multicolumn{2}{|c|}{ PublisherInfo } \\
\hline \hline PublisherName & $:$ & BioMed Central \\
\hline \hline PublisherLocation & $:$ & London \\
\hline \hline PublisherImprintName & $:$ & BioMed Central \\
\hline \hline
\end{tabular}

\title{
PharmInfoNet Drug Database
}

\begin{tabular}{|l|l|l||}
\hline \multicolumn{2}{|c|}{ ArticleInfo } \\
\hline \hline ArticleID & $:$ & 4275 \\
\hline \hline ArticleDOI & $:$ & $10.1186 /$ ccf-2000-webreport1182 \\
\hline \hline ArticleCitationID & $:$ & webreport1182 \\
\hline \hline ArticleSequenceNumber & $:$ & 16 \\
\hline \hline ArticleCategory & $:$ & Web report \\
\hline \hline ArticleFirstPage & $:$ & 1 \\
\hline \hline ArticleLastPage & $:$ & 2 \\
\hline \hline & & RegistrationDate : 2000-11-2 \\
\hline ArticleHistory & $:$ & OnlineDate \\
\hline ArticleCopyright & $:$ & Current Science Ltd2000-11-2 \\
\hline \hline ArticleGrants & $:$ & \\
\hline \hline ArticleContext & $:$ & 1305444 \\
\hline \hline
\end{tabular}




\section{Overview}

This site contains basic information about various drugs and provides links to original articles referencing the drug you are interested in. Drugs are listed alphabetically and can be searched for by generic name and tradename. The following information is given with every drug listed in the database: generic name; tradename; manufacturer; therapeutic class; indications; and links to articles and archives.

\section{Content}

The site is small (463 drugs listed currently). However, new entries are being added continually. The site is very simple to navigate even for a beginner.

\section{Other comments}

The site is regularly updated (at least three times a month).

\section{References}

1. PharminfoNet. [http://pharminfo.com/drugdb/db_mnu.html] 